\title{
ПРОФЕССИОНАЛЬНЫЕ ПРОБЫ В КОНТЕКСТЕ ПРОБЛЕМАТИКИ ПРОФЕССИОНАЛЬНОГО САМООПРЕДЕЛЕНИЯ МОЛОДЕЖИ
}

Кикава Н.С.

Профессиональное самоопределение молодежи в настоящее время является актуальной проблемой исследования важным фактором социализации, самореализации личности. Невозможно представить себе подростковый возраст без проблемы выбора профессии. Профессиональное самоопределения достаточно емкое понятие и во многом определяется взглядами и воззрениями представителей различных теоретических подходов и школ.

Так, например Е.А. Климов определял профессиональное самоопределение как процесс приобщения к профессиональной группе и постоянный поиск возможностей развития как субъекта труда [1]. Л.Д. Столяренко и В.Е. Столяренко рассматривают самоопределение как длительный процесс проходящий через всю жизнь, от возникновения профессиональных намерений и завершающийся окончанием трудовой деятельности [2]. Н.С. Пряжников, профессиональное самоопределение видел, как процесс, связанный с личностной самореализацией и поиском смысла выполняемой трудовой деятельности в контексте существующей социальной действительности оптанта [3]. Н.Ф. Родичев и С.Н. Чистякова рассматривают самоопределение как динамичный процесс формирования личностью системы базовых отношений, основных профессиональных и личностных компетенций, которые позволяют адаптироваться человеку в современных экономических и культурных условиях и принимать решения [4]

Таким образом, профессиональное самоопределение представляется как многоступенчатый процесс, охватывающий большую часть жизни индивида, связан с выбором своего места в жизни соотношения себя и профессионального сообщества, затрагивает отношения индивида к трудовой деятельности организации своего жизненного пути, самореализацию и нахождению смысла жизни. Под профессиональное самоопределение это еще и сопоставление своих индивидуально-личностных, физиологических особенностей, интересов и склонностей, ценностных ориентаций и установок, интеллектуальных способностей с требованиями профессиональной деятельности, контекстом и социальной средой, востребованностью выбираемой профессии. Профессиональное самоопределение включает в себя: профессиональную информацию, профессиональную диагностику, профессиональную консультацию, профессиональный отбор, профессиональную адаптацию, агитацию. В соответствии с проблематикой выбора профессии можно выделить три составляющие профориентационных задач с учетом их условного деления:

- когнитивно-информационная (информирование о мире профессий, состоянии рынка труда, содержательные компоненты той или иной трудовой деятельности, профессиональных образовательных программах и учреждениях); 
- мотивационно-ценностная (формирование у школьников всей гаммы побудительных мотивов, смыслообразуюших и профессиональных ценностей);

- предметно-деятельностная (составление, и реализация профессиональных планов, профессиональные пробы, моделирование трудовой деятельности).

В качестве целей профессиональной ориентации обозначены:

-повышение ценности предметных знаний как ресурса для получения соответствующего профессионального образования;

-развитие социально и профессионально значимых качеств и пред профессиональных компетентностей;

-корректировка профессиональных интересов и склонностей, обучающихся с целью повышения качества последующего профессионального обучения;

-углубленное знакомство школьника с профессией или с классом профессий в практико-ориентированной деятельности;

-формирование допрофессиональных знаний, умений, навыков, опыта практической работы в конкретной сфере профессиональной деятельности;

-осознание или рефлексия школьником приобретенных знаний и опыта деятельности во время профессиональной пробы в плане выбора предпочитаемого направления профессиональной подготовки и построения личной профессиональной перспективы.

Профессиональное самоопределение как процесс соотнесения себя с миром профессий и выстроенная целенаправленная траектория движения к профессионализации. Для этого на наш взгляд необходима деятельная, активная жизненная позиция подростка, которая вписывается в парадигму практикоориентированного подхода к выбору профессии.

На наш взгляд одним из значимых практикоориентированных направлений работы с подростками является профессиональная проба, значимая часть такого понятия как готовность к выбору профессии, способствующая погружению оптанта в профессиональную среду и формирующая возможности осуществления профессиональных выборов. Одним из важных условий профессиональной пробы является моделирование целостного профессионального процесса и максимального его детализации и погружение в атмосферу приближенной к профессиональной деятельности. И последним этапом будет являться сознательный и обоснованный выбор профессии.

\section{Литература}

1. Климов Е.А. Психология профессионального самоопределения. Ростов на/Д.: Изд-во «Феникс», 1996. - 512 с.;

2. Столяренко Л.Д., Столяренко В.Е. Психология и педагогика для технических вузов. - Ростов н/Д.: «Феникс», 2001. - 511 с.;

3. Пряжников Н.С. Профессиональное и личностное самоопределение. М.; Воронеж, 1996. - 246 с.

4. Чистякова С.Н. Проблема самоопределения старшеклассников при выборе профиля обучения // Педагогика. - 2005. - № 1. - С. 19-26; 